\title{
Performance Management Optimization of Virtual Music Concert at SMKN 12 Surabaya
}

\author{
Dhani Kristiandri ${ }^{1, *}$ Vivi E. Dewi ${ }^{1}$ Moh. Sarjoko ${ }^{2}$ Joko Winarko $^{3}$ Agus Suwahyono ${ }^{4}$ \\ ${ }^{1,2,3,4}$ Music Study Program, Languages and Arts Faculty, Universitas Negeri Surabaya \\ *Corresponding author. Email: dhanikristiandri@unesa.ac.id
}

\begin{abstract}
This study discusses the optimization of performance management at SMK Negeri 12 Surabaya. The purpose of this study was to describe the process of optimizing performance management at SMK Negeri 12 Surabaya and to find out the students' response to performance management training during the COVID-19 pandemic. It refers to a government regulation that prohibits face-to-face activities. However, during the COVID-19 pandemic, there were many innovations in organizing concerts. One of these innovations is the implementation of virtual shows. It was challenging to implement the concerts and rehearsal processes. Methods used in this study are a preliminary study or data collection of the target audience, material preparation, and determination of the implementation schedule, activities implementation, and evaluation design. A preliminary study or data collection of the target audience was carried out by listing the things needed by the training participants related to the training implementation. The data were obtained from a principal and teachers at SMKN 12 Surabaya. After collecting the data, the material preparation was conducted, including observation, discussion, and material identification. The activity results showed that the target audience's preliminary study/data collection went smoothly, and the data obtained were in accordance with what was needed.
\end{abstract}

\section{Keywords: Optimization, Performance management, Music concert, Virtual, SMKN 12 Surabaya}

\section{INTRODUCTION}

The Corona Virus from Wuhan, China, has almost spread to people worldwide, especially in Indonesia. The number of positive cases of Covid-19 in Indonesia is increasing day by day. The Indonesian government has made great efforts to break the chain of Covid-19 transmission in various regions. Due to the Corona Virus pandemic, there are significant changes toward human life and society in different aspects, especially education. The community is requested to stay at home and work from home to prevent the spread of Covid-19 transmission.

The community services (Pengabdian Kepada Masyarakat or $P K M$ ) are based on the fact that the education aspect in Indonesia has been carried out a teaching-learning process for all students online for approximately one year. This implementation is one of the government's efforts to prevent the spread of the Corona Virus by staying at home. In fact, the implementation of online teaching and learning is not entirely effective in improving the quality of education in Indonesia. However, this is the only way the Indonesian government must do so that the implementation of the teaching-learning process keeps going.

The online teaching-learning process is implemented at Primary School, Junior High School, Senior High School/Vocational School, and Higher Education. One educational institution that follows the government's appeal for virtual learning is SMK Negeri 12 Surabaya. SMKN 12 Surabaya is a secondary and vocational education school with many fields of expertise such as music, dance, drama, film, etc. The Covid-19 pandemic is a big challenge for the secondary and vocational schools where the students' output is required based on their qualified fields.

One of the fields of expertise at SMKN 12 Surabaya that has significantly been affected by the Covid-19 pandemic is the field of music expertise. It can be seen from the implementation of online principal instrument 
practices that it is not compelling enough. There are difficulties and obstacles in the course implementation of the principle instrument practices when educators have to indirectly correct students' musical playing techniques. It causes the students to be confused due to the educators' explanations which are always limited in virtual learning. Therefore, the increase in students' ability to play music cannot be seen significantly. The impact of the slow improvement in students' musical ability resulted in the concert's scheduled to be held.

The concert was held during the Covid-19 pandemic. It was challenging to implement because the concert and rehearsal processes could not be implemented directly. It refers to Indonesian government regulation which prohibits offline/face-to-face activities. Yet, many innovations were made in organizing the concert during the Covid-19 pandemic. One of these innovations is the implementation of a virtual music concert. The virtual concert management is carried out by players/musicians who record their own performance from their homes. After that, the performance results are collected to be combined then mixed. Nevertheless, the process requires an excellent management implementation. The need for excellent management implementation includes score management, rehearsal management, and recording and broadcasting management. Furthermore, good management training is needed for students of SMK Negeri 12 Surabaya. Hence, the PKM activity focuses on optimizing the management of virtual music concert performance. This activity collaborated with an educational institution, namely SMK Negeri 12 Surabaya.

Activities carried out by individuals in thoughts, ideas, and concepts are delivered through a learning activity. The learning activity can be done in various places, whether in formal, non-formal, or informal education. Learning is a process of interaction between students and educators in a learning environment with the support of learning resources [1]. Further, it can be said that learning is a form of activity that involves the role of teachers and students to achieve a learning goal. Learning objectives can be achieved since there are several aspects such as cognitive, psychomotor, and effectiveness in the learning process. Therefore, a learning process can be successful if it fulfills these three aspects.

In the school's teaching and learning activities, every educator has various ways and perspectives in conducting a learning process. According to Johnson it indicates that, whatever the subjects are, the teacher should have choices to arrange the lesson in every class so that the students a) are able to challenge themselves and give out of their best works to see who is the best (competition), b) the students work independently based on their own learning objectives for achieving the criteria of excellence (individualism), and c) the students cooperate each other in small groups to ensure all members for mastering the given materials (cooperation) [2].

One aspect that is expected to occur in the teaching and learning activities is practical learning. An effective learning is good learning that students like and acquire specific skills, knowledge, and attitudes [3]. Besides, learning is practical if there are changes in cognitive, affective, and psychomotor aspects. Meanwhile, there are four criteria for effective learning as follow: accuracy in mastery, performance speed, learning transfer rates, and retention rates [4]. In addition, Slavin in Djamarah stated four aspects to determine the effectiveness of learning, including the quality of learning, the suitability of the level of learning, incentives, and time [5].

Learning can be decided to be effective if the learning can achieve the expected goals. Also, effective learning can overcome students' learning difficulties. It can be seen from the students' difficulties experiences (before and after learning) that have been decreased.

\subsection{Performance Management}

\subsubsection{Music Recording Elements}

Bill Richardson explained that music recording has various elements as the characteristics of the recording process itself. According to the characteristics, the music recording is divided into two types, as follows:

\section{Equipment}

\section{a. Digital Recording}

A recording system can directly convert the analog signal from instruments and vocals into a midi format. Digital media devices use both software and hardware devices. Thus, this system is more manageable and less complicated.

\section{b. Analog Recording}

An analog system recording is carried out by using a tape recording. The analog recording can produce a thicker sound because it uses Vinyl tape.

\section{Recording Technique}

\section{a. Live Recording}

A recording technique in which all the sound produced is recorded on one track. The advantage of this live recording technique is that the musicians get the feel and energy of the recorded song because they play the instrument simultaneously. On the other hand, the 
disadvantage is that the music play must be cohesive. All personnel must master the materials correctly because if there are some errors in this technique that cannot be edited, they must be repeated from the beginning.

\section{b. Multitrack Recording}

A recording technique is recorded by each instrument in turn then stored on a separate track. Besides, in this technique, the musicians can repeat their part frequently. Even if there are several errors, the musicians do not need to repeat the entire song.

\section{Sound equipment}

It works as a medium of channeling messages in musical works, which is divided into:

\section{a. Vocal cords (vocal folds)}

It produces human vocal sounds resulting from vibrations in the vocal cord membranes within the larynx.

b. Music Instruments

\section{- Vodaphone}

It is produced by the instrument body itself, such as glockenspiel.

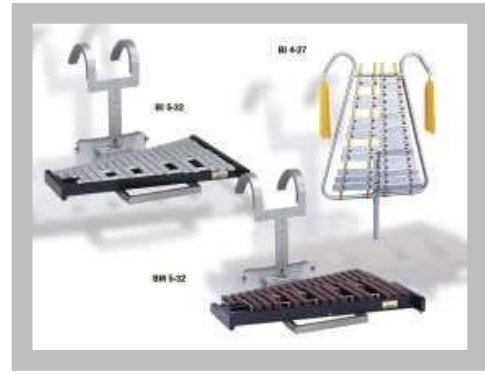

Figure 1 Glockenspiel [6]

\section{- Aerophone}

Wind instruments produce sound by focusing air into the mouthpiece, which causes a vibration such as flutes, saxophone, etc.

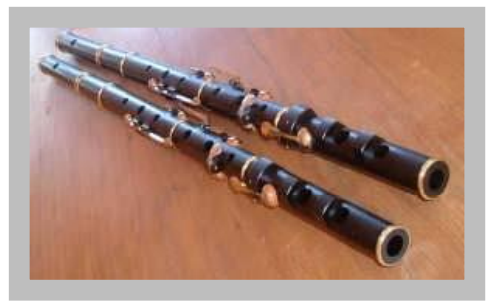

Figure 2 Saxophone [7]

\section{- Membranophone}

A membrane stretched over one or both open ends of a drum to vibrate then resonates the sound through the drum.

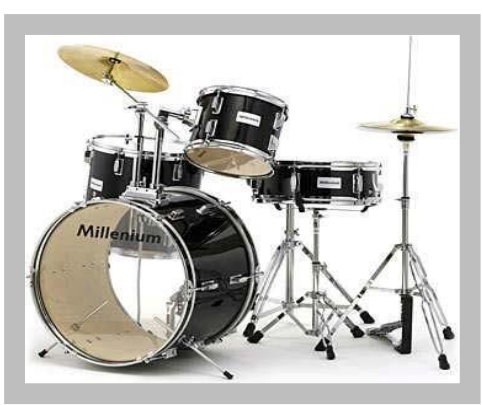

Figure 3 Drum [7]

\section{- Chordophone}

A stringed instrument produces sound by the vibration of stretched strings such as violin, guitar, and cello.

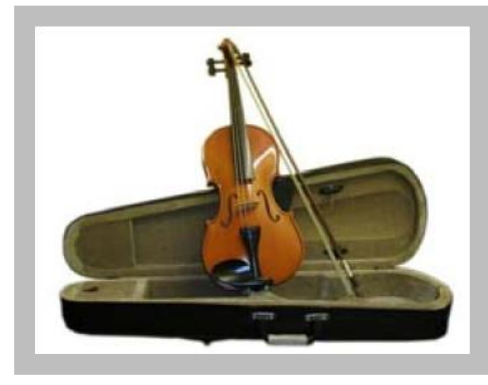

Figure 4 Violin [7]

\section{- Electrophone}

An electrophone is a musical instrument whose sound amplification is assisted or caused by an electric power such as a keyboard instrument, electronic organ, and synthesizer.

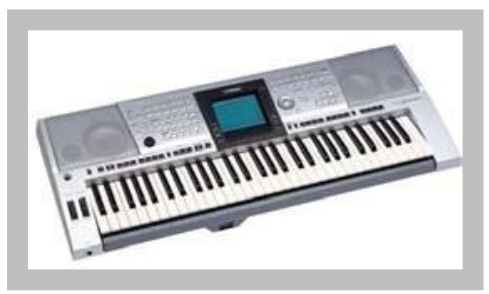

Figure 5 Keyboard [8]

\subsection{Stages of Music Recording}

In the process of recording music, there are steps carried out, namely: 


\section{Tracking.}

Before an arrangement of music is finalized, there is an instrument that accompanies a song. Each device is recorded on a track. Technically, the sound is converted into magnetic waves then the recorder receives the signal. Ideally, the recorded sound source is similar enough to the original sound. If using a computer such as a DAW system, the signal becomes midi format. Yet, if using analog recording such as a DAT system, the signal remains analog.

2. Overdub

Overdub is the extent of a new recording track to the existing recording track. For instance, doubling the guitar sound, etc.

\section{Editing}

Editing is the process of replacing, cutting, and completing certain parts into a perfect form. In the digital world, the editing process is carried out with audio editing software facilities.

4. Mixing

Mixing is a process of combining the recorded tracks that have been composed and equalizing all the recorded tracks.

\section{Equalizing}

Equalizing is creating sound characters by amplifying or reducing sound frequencies such as Low, Low-Mid, High-Mid, and High. This process requires ear sharpness in hearing so that different frequencies do not collide with each other. Eventually, the recorded sound must be clear, bright, and not broken.

\section{Sound Effect}

The sound effect provides various stronger characters such as Delay, Chorus, Compresi, Noise Gate, Limiter, etc. This final touch will make the music ready to listen to after conducting the mastering.

7. Mastering

It aims to eliminate the effects of "hiss" and "hum," reduce the excessive sibilance (ess), compress harsh frequencies, accomplish as well as equalize the tracks, also set the standard of volume. Eventually, our music is recorded into the cassette, $\mathrm{CD}, \mathrm{MP} 3$, or other final formats to be played on various audio players.

\subsection{The Technology of the Music Recording}

Two significant technological advances for the music recording world lately are midi sequencing and diskbased digital audio recording. Midi sequencing is the technology that aims to record the sound in the midi format (digital). Meanwhile, the disk-based digital audio recording is the technology that seeks to record and playback the data of music note that has been formatted previously.

The technique of recording musical notes uses a medium of midi sequencing. This medium can be in devices such as Roland MC-500, music instruments such as Korg X3, and computer programs such as Cakewalk, Pro Audio 9, SONAR, Steinberg Cubase SX, Ableton, ACID, Power tracks, etc.

The technique principle is that music arrangements played by keyboard or guitar are connected to the sequencer through a midi cable. Further, to playback the arrangements, a note recorder is connected to a synthesizer instrument, producing sounds according to the midi data sent by the note recorder (sequencer). Then the data obtained are stored in a hard disk.

\subsection{Music Recording Studio Definition}

A music recording studio is where musicians can record their musical works from various musical instruments combined into one then process to music or song with the maximum result.

The music recording studios usually have their music specialization. Some of them tend to focus on dangdut, campursari, pop, and rock. All musicians whose different musical genres can do the recording process.

The recording studio is designed to use the basic principles of room acoustics for accurate sound recording. This includes the use of materials and room dimensions. Ideally, a recording studio should have several spaces such as a recording room, control room, and mixing room. Each room has its configuration in combining materials of walls, ceilings, and floors. Generally, the room design used is the design to record directly in one room. This is carried out in order to control the quality of vibration that occurs in the room.

Furthermore, a recording studio has good acoustic quality since it has good soundproof, where the music room has a good level of soundproofing to control unwanted sounds at all frequencies. 


\subsection{Music Recording Studio Organizational Structure}

The management system in several big label recording studios is divided into several different parts. Each part holds its responsibilities to keep going on the same goal of promoting music in the music market to enjoy the music.

\section{Chief Operating Officer (CEO)}

The person knows the whole process of activities in a studio recording and is responsible for receiving division reports.

\section{Artist and Repertoire}

They are assigned to find new talents in the music field, either amateurs or new to the world of recording. Their duties are listening to songs demos, connecting artists to the right producers, and providing critique and suggestions for each record made.

\section{Music Production}

It is responsible for recording music starting from the practice process, tracking music, until mastering the pieces of music.

4. Sales and Marketing

They are assigned to advertise products to sellers and distributors.

\section{Promotion}

It holds a vital role in introducing new products from a label company.

\section{Publicity}

This division is responsible for conducting the interview, discussing album materials, and the background of musicians who will be recording. This publication department is also in charge of involving musicians who are considered potential in a prestigious music event.

7. Art

In charge of all visual arts displays such as album cover design, company logo, and advertisement creation.

8. Legal

Legal is a team consisting of lawyers from a law firm where they will be in charge of negotiating and taking care of all kinds of things related to the design of music recording contracts.

\section{Accounting and administration}

This division manages the storage of documents related to the company's daily financial transactions and employees' payroll processes.

\section{METHODS}

The research method used is quantitative and qualitative research methods (mix methods). This study applies a qualitative descriptive approach, namely research that requires an explanation of the circumstances that occur without explaining the object under investigation. Qualitative research intends to understand phenomena about what is experienced by research subjects, for example, behavior, perceptions, motivations, actions, and others holistically and utilizing descriptions in the form of words and language in a special context that is natural and with utilizing various natural methods [9].

The object of research is something that refers to the actions of the subject. In this case, the object is data, habit, knowledge, as action. The object of this research is "Optimization Process of Music Concert Performance Management at SMK Negeri 12 Surabaya".

The location where the research is located is at the residence of the research team via the zoom-meeting platform. Due to the Covid-19 pandemic, the research team could not meet directly with participants in music concert performance management training, so the solution was to use the zoom meeting platform and social media to communicate. The researcher chose the zoom meeting platform and social media to be more flexible in discussing and adding insight to the research process.

Data as a reference material that has an important role in a study. The collection method selects which data is the most appropriate so that the most valid and reliable data is obtained [10]. To get maximum, good, and proper results of data collection techniques are needed in qualitative research. The method used as a reference in the research is Observation and Documentation.

Furthermore, to evaluate the implementation of this training, the research team applied quantitative research methods. The researcher used descriptive statistics as a data analysis technique. The data collection instrument used one type of questionnaire, namely a closed questionnaire. Presentation of data in this study through numbers in percentages and tables.

\section{RESULTS AND DISCUSSION}

The results and discussion show that the preliminary study or data collection of the target audience was carried 
out by recording the things needed by the training participants related to the implementation of the training. The data were obtained from the Principals and Teachers at SMKN 12 Surabaya. The preparation of the material is carried out after collecting data on the needs of the trainees. The next action is to observe, discuss, and identify materials tailored to the training participants and then divide the tasks to each member of the PKM. It is hoped that the material that has been prepared is in accordance with the needs of the trainees. The implementation schedule is determined in good coordination with the leaders or teachers of SMKN 12 Surabaya for the implementation schedule, which does not interfere with the activities between the implementers and the target audience.

The activity results showed that the target audience's preliminary study/data collection went smoothly, and the data obtained were in accordance with what was needed. Material preparation activities are also adjusted to the preliminary study data obtained, namely the preparation of score management materials, practice management, and recording and broadcasting management. The implementation of the activity also went smoothly with the enthusiasm and participation of students at SMKN 12 Surabaya, which was very high.

The evaluation results of this training program were analyzed using quantitative methods with descriptive statistics, namely looking at the results of a questionnaire regarding the responses of SMKN 12 students of the music concert performance management training. The results showed that from 70 respondents, 68 respondents answered agree and had a positive perception of implementing performance management training. It showed a percentage of $97 \%$, and two respondents who answered disagreed and had negative perceptions about implementing performance management training for students of SMKN 12 Surabaya by showing the percentage of $3 \%$.

Meanwhile, performance management training in delivering music recording material includes various elements of music recording, stages of music recording, music recording technology, music genres, and music recording organizational structure. Music recording includes equipment (digital and analog recordings) and recording techniques (live recording and multitrack recording). In addition, the stages of music recording are tracking, overdub, editing, mixing, equalizing, sound effects, and mastering. Music genres that can be included in the music recording process are classical music, gospel, jazz, traditional music, funk, blues, rock, pop, country, electronic, ska, dub, reggae, hip hop, rap, and rapcore. Meanwhile, the organizational structure of music recording is in the form of Chief Operating Officer or Chief Executive Officer (CEO), Artist and Repertoire, Music Production, Sales and Marketing, Promotion, Publicity, Art, Legal, Accounting, and Administration.

\section{CONCLUSION}

The concert activity, which was held during the COVID-19 pandemic, was challenging to implement because the concerts and rehearsal processes that were carried out directly could not be carried out. This refers to a government regulation that prohibits face-to-face activities. However, during the COVID-19 pandemic, many innovations were made in organizing concerts. One of these innovations is the implementation of virtual shows. The concert management process is virtually carried out in a way where players record their performances from their homes, and after that, they are collected to be combined and mixed. However, the process requires the implementation of excellent management. The need for perfect management implementation includes score management, rehearsal management, and recording and broadcasting management. Furthermore, good management training is needed for students of SMK Negeri 12 Surabaya. Therefore, the community services (Pengabdian Kepada Masyarakat or $P K M)$ activity optimizes virtual music concert performance management. This activity is also collaborating with an educational institution that is SMK Negeri 12 Surabaya.

Methods used in this study are a preliminary study or data collection of the target audience, material preparation, and determination of the implementation schedule, activities implementation, and evaluation design. A preliminary study or data collection of the target audience was carried out by listing the things needed by the training participants related to the training implementation. The data were obtained from a principal and teachers at SMKN 12 Surabaya. After collecting the data, the material preparation was conducted, including observation, discussion, and material identification. Moreover, each member of PKM was handed out the tasks that these materials have arranged according to trainees' needs. Also, the determination of the implementation schedule was carried out in good coordination with the principal or teachers of SMKN 12 Surabaya. The implementation schedule was required to not interfere with other activities between the manager and the target audience.

The activity results showed that the target audience's preliminary study/data collection went smoothly, and the data obtained were in accordance with what was needed. Material preparation activities are also adjusted to the 
initial study data obtained, namely the preparation of score management materials, practice management, and recording and broadcasting management. The implementation of the activity also went smoothly with the enthusiasm and participation of students at SMKN 12 Surabaya, which was very high. The evaluation results of this training program were analyzed using quantitative methods with descriptive statistics, namely looking at the results of a questionnaire regarding the responses of SMKN 12 students toward the training of music concert performance management. The results showed that from 70 respondents, 68 respondents answered agree and had a positive perception of implementing performance management training. The percentage showed $97 \%$, and two respondents who answered disagreed and had negative perceptions about implementing performance management training for students of SMKN 12 Surabaya by showing the percentage of $3 \%$.

\section{REFERENCES}

[1] H. Rahyubi, "Teori-teori belajar dan aplikasi pembelajaran motorik," Bandung Nusa Media, 2012.
[2] D. W. Johnson, R. T. Johnson, and E. J. Holubec, "Colaborative learning: strategi pembelajaran untuk sukses bersama,” Bandung Nusa Media, 2010.

[3] R. A. Reiser and W. Dick, Instructional planning: A guide for teachers. Allyn and Bacon, 1996.

[4] C. M. Reigeluth and A. A. CARR, "Understanding Instructional Theory," in Instructional-Design Theories and Models, Volume III, Routledge, 2009, pp. 15-38.

[5] S. B. Djamarah and A. Zain, "Strategi belajar mengajar," Jakarta: Rineka Cipta, vol. 46, 2006.

[6] "Taiwan Manufacturers Directory, China Manufacturers - all products." https://www.allproducts.com/.

[7] "Music Instrument." www.vijaiacademy.com.

[8] S. Syaiful, "MUSIK _ Syaiful's Blog," 2009. http://syaifulyes.wordpress.com/musik .

[9] L. J. Moleong, "Metode Penelitian Kualitatif, cetakan ke-36, Bandung: PT," Remaja Rosdakarya Offset, 2017.

[10]D. Sugiyono, "Metode penelitian pendidikan pendekatan kuantitatif, kualitatif dan R\&D,” 2013. 